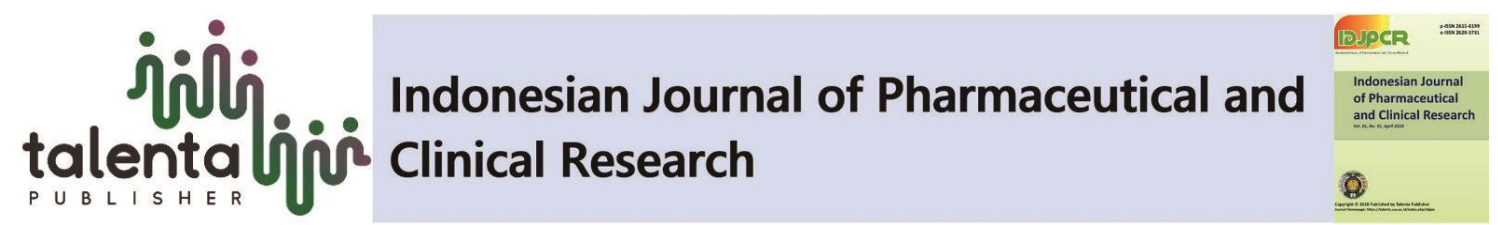

\title{
Poguntano Herba Extract Immunostimulant Activities (Picriafel-terraeLour), in Immunosupression Rats Infected by Staphylococcus aureus Against Total Leukocytes and Differential Leukocytes
}

\author{
Anggitha Ningtias, Rosidah*, Yuandani \\ Department of Pharmacology, Faculty of Pharmacy, Universitas Sumatera Utara, Medan, Indonesia
}

\begin{abstract}
Poguntano (Picriafel-terraeLour.) is a medicinal plant in North Sumatra that has been used in traditional medicine to treat degenerative diseases.Poguntano extract contains flavonoid compounds that have the potential to be developed into immunomodulators. This study showed the immunostimulant activity of poguntano herb n-hexane extract (PHNHE), poguntano herb ethyl acetate extract (PHEAE) and poguntano herb ethanol extract (PHEE) in immunosuppressed rats infected with Staphylococcus aureus. The evidence of poguntano herb as an immunomodulator was carried out by testing total leukocytes and differential leukocytes. Poguntano herb n-hexane extract (PHNHE) can not increase the total and differential leukocytes; Poguntano herb ethyl acetate extract (PHEAE) and poguntano herb ethanol extract (PHEE) can increase the total and differential leukocytes in immunosuppressed rats induced by Staphylococcus aureus.
\end{abstract}

Keyword: Picria fel-terrae Lour. immunostimulants, immunosuppressants, Staphylococcus aureus

\begin{abstract}
Abstrak. Poguntano (Picriafel-terrae Lour.) merupakan salah satu tanaman obat di Sumatera Utara yang telah digunakan dalam pengobatan tradisional untuk mengatasi penyakit degeneratif. Ekstrak poguntano mengandung senyawa flavonoid yang berpotensi dikembangkan menjadi imunomodulator. Penelitian ini menunjukkan adanya aktivitas imunostimulan ekstrak n-heksana herba poguntano (ENHP), ekstrak etil asetat herba poguntano (EEAHP) dan ekstrak etanol herba poguntano (EEHP) pada tikus imunosupresi yang diinfeksi Staphylococcus aureus. Pembuktian herba poguntano sebagai imunomodulator dilakukan dengan tahapan uji total leukosit dan diferensial leukosit. Ekstrak n-heksana herba poguntano (ENHHP) tidak dapat meningkatkan total leukosit dan diferensial leukosit; Ekstrak etil asetat herba poguntano (EEAHP) dan ekstrak etanol herba poguntano (EEHP) dapat meningkatkatkan total leukosit dan diferensial leukosit pada tikus imunosupresi yang di infeksi Staphylococcus aureus.
\end{abstract}

Kata Kunci: Herba poguntano, imunostimulan, imunosupresi, Staphylococcus aureus

Received 13 January 2021 | Revised 18 May 2021 | Accepted 10 May 2021

*Corresponding author at: Department of Pharmacology, Faculty of Pharmacy, Universitas Sumatera Utara, Medan, Indonesia

E-mail address: rosidah@usu.ac.id

Copyright (c) 2021 Published by Talenta Publisher, Print ISSN : 2615-6199, Online ISSN : 2620-3731

Journal Homepage: https://talenta.usu.ac.id/index.php/idjpcr 


\section{Introduction}

Immune system-mediated disease is a significant problem in developing countries. An environment that is rich in various types of pathogenic microorganisms, for example bacteria, viruses, fungus, protozoa and parasites is a factor that causes infection in humans [1].

Infections that occur in normal people are generally brief and rarely leave permanent damage. This is because the human body has a system called the immune system that responds and protects the body against pathogenic elements that can cause disease. When the function and number of theimmune system are low, exposure to pathogenic microorganisms can cause various diseases, especially those related to infectious diseases and when the function and number of the immune system is excess, it will attack itself or it is called an autoimmune disease [2].

Immunosuppressive drugs are widely used to improve clinical symptoms of autoimmune diseases [3]. One of the immunosuppressive drugs is cyclophosphamide. However, immunosuppression by cyclophosphamide can lead to increased susceptibility to infection [4]. Cyclophosphamide suppresses the bone marrow resulting in massive hemopoietic cell depletion, one of which is characterized by a decrease in the number of leukocytes, weight loss, spleen and thymus weight, antibodies, bone marrow cells, T and B cell proliferation, and NK cell activity [5]. A decrease in the immune system can make the body vulnerable to disease attacks. Therefore, we need a compound that can work to overcome the immunosuppressive effects of cyclophosphamide.

Immunomodulators are substances or drugs that can modulate the function and activity of the immune system. Based on how it works, immunomodulators are divided into 2 groups, namely immunostimulators and immunosuppressors. Immunostimulators function to increase the function and activity of the immune system while immunosuppressors function to suppress the activity of the immune system [6].

The results of the initial phytochemical screening of the Picriafel-terrae Lour extract showed the presence of flavonoids, alkaloids, glycosides, saponins, tannins and steroids / triterpenoids [7],[8],[9].

Based on the description above, this study aims to determine the effect of immunostimulant activity of poguntano herb extract in immunosuppressed rats infected with Staphylococcus aureus on total and differential leukocytes.

\section{Materials and Methods}

\subsection{Chemicals and reagents}

The chemicals used in this study were n-hexane, ethyl acetate, and ethanol which were purchased from Smart Lab (Indonesia). Staphylococcus aureus bacteria were obtained from the Microbiology Laboratory, Faculty of Pharmacy, the University of Sumatera Utara. Phosphate buffer saline (PBS; Sigma, USA), sodium carboxymethty cellulose (Na CMC; sigma, USA) levamisole (Askamex ${ }^{\circledR}$; Soho, Indonesia), and cyclophosphamide (Kalbe, Indonesia).

\subsection{Extraction procedure}

The herb Picriafel-terrae Lour were dried, ground, then extracted by maceration method using nhexane, ethyl acetate and ethanol as solvents. Briefly, the dried plant material $(500 \mathrm{~g}$ of herb Picriafel-terrae Lour) was macerated with n-hexane, ethyl acetate and ethanol. Then, the solvent was removed using a rotary evaporator to yield n-hexane, ethyl acetate and ethanol extract of herb Picriafel-terrae Lour. 


\subsection{Antigen preparation}

Staphylococcus aureus bacteria were obtained from the Microbiology Laboratory, Faculty of Pharmacy, University of Sumatera Utara. Staphylococcus aureus bacteria to be used are regenerated on nutrient agar media and incubated for 24 hours at $37^{\circ} \mathrm{C}$. After 24 hours of incubation, the growing bacterial colonies were transferred to liquid nutrient broth aseptically using sterile ose and incubated again for 24 hours at $37^{\circ} \mathrm{C}$. Next, take $1 \mathrm{~mL}$ and add $9 \mathrm{~mL}$ of new nutrient broth. Then the cell concentration was calculated using the spectrophotometry method until the concentration of $10^{9}$ cells / mL. After getting the bacterial cell concentration of $10^{9}$ cells / mL, then centrifuge at 2500 rpm for 25 minutes. The supernatant was discarded. Then, the cells were resuspended with $1 \mathrm{~mL}$ of PBS [10].

\subsection{Experimental animals}

Male Wistar rats weighing 180-200 g were used, divided into 12 groups of 4 rats each group and used in the experiments. Group I served as normal rats received vehicle carboxymethyl cellulose $\mathrm{Na}$ $0.5 \%$, group II infected by Staphylococcus aureus bacteria on day 4, induced by cyclophosphamide doses of $70 \mathrm{mg} / \mathrm{kg}$ body weight on day 8 and 13 and were administered carboxymethyl cellulose $\mathrm{Na}$ $0.5 \%$ orally once daily for 14 consecutive days, group III were administered levamisol $25 \mathrm{mg} / \mathrm{kg}$ body weight orally once daily for 14 consecutive days, infected by Staphylococcus aureus bacteria on day 4 and induced by cyclophosphamide doses of $70 \mathrm{mg} / \mathrm{kg}$ body weight on day 8 and 13 , groups IV -XII received variation of doses of 50,100 and $200 \mathrm{mg} / \mathrm{kg}$ body weight of the extract of herb Picriafel-terrae Lour. respectively. the rats were administered extract of herb Picriafel-terrae Lour once daily for 14 consecutive days, infected by Staphylococcus aureus bacteria on day 4 and induced by cyclophosphamide doses of $70 \mathrm{mg} / \mathrm{kg}$ body weight on day 8 and 13 .

On 15 day the animals were anesthetized using ketamine, blood was drawn from the heart to obtain plasma. Taking plasma, blood is collected in a tube containing an anticoagulant, used to measure the total leukocytes and differential leukocytes.

\subsection{Measurement of total leukocyte and leukocyte differential}

The leukocyte differential measurement includes the measurement of neutrophils, lymphocytes, eosinophils, and basophils. After the 15th day, as much as $1 \mathrm{~mL}$ of blood was taken into a tube containing the anticoagulant and checked for the total number of leukocytes and the differential of leukocytes. at the Regional Health Laboratory Center of the city of Medan, Sumatera Utara.

\subsection{Statistical analysis}

The data were presented as mean \pm SD and analyzed with SPSS software using a one-way analysis of variance (ANOVA) and followed by the post hoc Tukey test. Values of $P<0.05$ were considered significantly different.

\section{Results and Discussion}

\subsection{Results of total leukocyte measurement}

Table 1 shows that ENHHP was not significantly different from the negative group ( $\mathrm{p}>0.05)$. EEAHP at a dose of $50 \mathrm{mg} / \mathrm{kg}$ bw was significantly different from the negative, levamisol and normal groups ( $\mathrm{p}<0.05$ ). EEAHP at a dose of 100, $200 \mathrm{mg} / \mathrm{kg}$ bw and EEHP at a dose of 50, 100, 
$200 \mathrm{mg} / \mathrm{kg}$ bw were significantly different from the negative group ( $\mathrm{p}<0.05)$. EEAHP at a dose of $100,200 \mathrm{mg} / \mathrm{kg}$ bw and EEHP at a dose of 50,100, $200 \mathrm{mg} / \mathrm{kg}$ bw were not significantly different from the levamisol and normal groups ( $\mathrm{p}>0.05$ ). EEAHP at a dose of 100, $200 \mathrm{mg} / \mathrm{kg} \mathrm{bw}$ and EEHP at a dose of 50,100, $200 \mathrm{mg} / \mathrm{kg}$ bw were able to increase total leukocytes.

Table 1. Effect of poguntano herb extract on total leukocyte in immunosupressionrats induced by Staphylococcus aureus

\begin{tabular}{cc}
\hline Groups & Leukocyte $\mathbf{1 0} / \mathbf{L}(\mathbf{M e a n} \pm$ SD) \\
\hline Normal control & $6.79 \pm 0.40^{\mathrm{b}}$ \\
Negative control & $3.66 \pm 0.38^{\mathrm{ac}}$ \\
Levamisole & $6.59 \pm 0.19^{\mathrm{b}}$ \\
PHNHE $50 \mathrm{mg} / \mathrm{kg}$ bw & $3.36 \pm 0.84^{\mathrm{ac}}$ \\
PHNHE $100 \mathrm{mg} / \mathrm{kg}$ bw & $3.39 \pm 0.17^{\mathrm{ac}}$ \\
PHNHE $200 \mathrm{mg} / \mathrm{kg}$ bw & $3.36 \pm 0.22^{\mathrm{ac}}$ \\
PHEAE $50 \mathrm{mg} / \mathrm{kg}$ bw & $5.14 \pm 0.52^{\mathrm{abc}}$ \\
PHEAE $100 \mathrm{mg} / \mathrm{kg} \mathrm{bw}$ & $6.04 \pm 0.35^{\mathrm{b}}$ \\
PHEAE $200 \mathrm{mg} / \mathrm{kg}$ bw & $6.08 \pm 0.42^{\mathrm{b}}$ \\
PHEE $50 \mathrm{mg} / \mathrm{kg}$ bw & $5.94 \pm 0.42^{\mathrm{b}}$ \\
PHEE $100 \mathrm{mg} / \mathrm{kg}$ bw & $6.02 \pm 0.30^{\mathrm{b}}$ \\
PHEE200 $\mathrm{mg} / \mathrm{kg}$ bw & $6.22 \pm 0.47^{\mathrm{b}}$ \\
\hline
\end{tabular}

Information:

PHNHE (poguntano herb n-hexane extract)

PHEAE (poguntano herb ethyl acetate extract)

PHEE (poguntano herb ethanol extract)

a. Sig $(\mathrm{P})<0.05$ there was a significant difference with the normal control group

b. Sig $(\mathrm{P})<0.05$ there was a significant difference with the negative group

c. Sig $(\mathrm{P})<0.05$ there was a significant difference with the levamisole group

This study showed that cyclophosphamide was able to significantly reduce the total number of leukocytes. The decrease in the total number of leukocytes in this study was an effect on the administration of cyclophosphamide. This is due to the suppressive effect of cyclophosphamide on the bone marrow which will inhibit the formation of blood cells including leukocytes [11].

Based on the results of research, ethyl acetate extract and ethanol extract of poguntano herbs can increase total leukocytes, an increase in the number of leukocytes is due to the herbal extract of poguntano containing flavonoids which can activate the lymph system so that it can increase the production of white blood cells [12].

\subsection{The results of differential measurement of leukocytes}

Blood cells involved in the immune response are derived from pluripotent hematopoytic stem cells. The stem cells then differentiate into two different pathways, namely: myeloid and lymphoid. Myeloid consists of polymorphonuclear granulocytes (basophils / mass cells, neutrophils, 
eosinophils), monocytes / macrophages and megakaryocytes / platelets, while lymphoids consist of T lymphocytes, B lymphocytes, and NK cells [13]. Differential measurement of leukocytes using a tool used, namely the haematology analyzer (Cell-Dyn 1800). There are five parameters that represent the differentiation of white blood cells, namely lymphocytes, neutrophils, basophils, eosinophils, and monocytes. Comparison of the differential number of leukocytes can be seen in table 2 .

Table 2. Effect of poguntano herb extract on leukocyte differential in immunosupressionrats induced by Staphylococcus aureus

\begin{tabular}{|c|c|c|c|c|c|}
\hline Groups & $\begin{array}{c}\text { Lymphocyte \% } \\
\text { (Mean } \pm \text { SD) }\end{array}$ & $\begin{array}{c}\text { Neutrophil \% } \\
(\text { Mean } \pm \text { SD) }\end{array}$ & $\begin{array}{l}\text { Basophil \% } \\
(\text { Mean } \pm \text { SD) }\end{array}$ & $\begin{array}{l}\text { Eosinophil\% } \\
\text { Mean } \pm \text { SD) }\end{array}$ & $\begin{array}{c}\text { Monocyte \% } \\
(\text { Mean } \pm \text { SD) }\end{array}$ \\
\hline $\begin{array}{l}\text { Normal } \\
\text { control }\end{array}$ & $25.00 \pm 1.41^{\mathrm{b}}$ & $74.50 \pm 1.20^{\mathrm{b}}$ & $3.25 \pm 0.95^{\mathrm{b}}$ & $4.25 \pm 0.57^{b}$ & $4.50 \pm 1.29^{\mathrm{b}}$ \\
\hline $\begin{array}{l}\text { Negative } \\
\text { control }\end{array}$ & $16.75 \pm 0.95^{\mathrm{ac}}$ & $54.00 \pm 3.46^{\mathrm{ac}}$ & $1.00 \pm 0.81^{\mathrm{ac}}$ & $0.75 \pm 0.95^{\mathrm{ac}}$ & $0.75 \pm 0.95^{\mathrm{ac}}$ \\
\hline Levamisole & $23.0 \pm 1.41^{\mathrm{b}}$ & $73.25 \pm 1.70^{\mathrm{b}}$ & $3.00 \pm 0.81^{\mathrm{b}}$ & $4.00 \pm 0.95^{\mathrm{b}}$ & $4.25 \pm 0.95^{\mathrm{l}}$ \\
\hline $\begin{array}{l}\text { PHNHE } 50 \\
\mathrm{mg} / \mathrm{kg} \text { bw }\end{array}$ & $17.0 \pm 1.41^{\mathrm{ac}}$ & $56.5 \pm 1.91^{\mathrm{ac}}$ & $0.75 \pm 0.95^{\mathrm{ac}}$ & $1.00 \pm 0.81^{\mathrm{ac}}$ & $1.00 \pm 0.81^{\mathrm{ac}}$ \\
\hline $\begin{array}{l}\text { PHNHE } 100 \\
\mathrm{mg} / \mathrm{kg} \mathrm{bw}\end{array}$ & $17.75 \pm 0.95^{\mathrm{ac}}$ & $56.00 \pm 3.55^{\mathrm{ac}}$ & $1.25 \pm 0.95^{\mathrm{ac}}$ & $1.25 \pm 1.29^{\mathrm{ac}}$ & $1.25 \pm 0.95^{\mathrm{a}}$ \\
\hline $\begin{array}{l}\mathrm{PHNHE} 200 \\
\mathrm{mg} / \mathrm{kg} \mathrm{bw}\end{array}$ & $18.00 \pm 0.81^{\mathrm{ac}}$ & $53.00 \pm 3.55^{\mathrm{ac}}$ & $2.25 \pm 1.29^{\mathrm{b}}$ & $2.00 \pm 1.25^{\mathrm{a}}$ & $1.00 \pm 1.41^{\mathrm{a}}$ \\
\hline $\begin{array}{l}\mathrm{PHEAE} \\
\mathrm{mg} / \mathrm{kg} \text { bw }\end{array}$ & $21.5 \pm 1.29^{\mathrm{ab}}$ & $67.00 \pm 3.55^{\mathrm{abc}}$ & $2.00 \pm 0.8^{\mathrm{b}}$ & $2.00 \pm 0.81^{\mathrm{a}}$ & $1.50 \pm 1.29^{\mathrm{a}}$ \\
\hline $\begin{array}{l}\text { PHEAE } 100 \\
\mathrm{mg} / \mathrm{kg} \text { bw }\end{array}$ & $22.25 \pm 2.21^{\mathrm{b}}$ & $72.50 \pm 1.29^{b}$ & $2.75 \pm 0.95^{\mathrm{b}}$ & $2.25 \pm 0.95^{\mathrm{b}}$ & $2.00 \pm 0.57^{\mathrm{b}}$ \\
\hline $\begin{array}{l}\text { PHEAE } 200 \\
\mathrm{mg} / \mathrm{kg} \mathrm{bw}\end{array}$ & $23.00 \pm 1.63^{\mathrm{b}}$ & $72.75 \pm 1.25^{\mathrm{b}}$ & $3.00 \pm 0.81^{\mathrm{b}}$ & $2.75 \pm 1.25^{\mathrm{b}}$ & $4.00 \pm 0.81^{\mathrm{b}}$ \\
\hline $\begin{array}{l}\mathrm{PHEE} \\
\mathrm{mg} / \mathrm{kg} \text { bw }\end{array}$ & $22.00 \pm 0.81^{\mathrm{b}}$ & $70.25 \pm 1.70^{b}$ & $2.25 \pm 0.95^{\mathrm{b}}$ & $2.25 \pm 0.95^{\mathrm{b}}$ & $2.00 \pm 1.41^{\mathrm{b}}$ \\
\hline $\begin{array}{l}\text { PHEE } 100 \\
\mathrm{mg} / \mathrm{kg} \text { bw }\end{array}$ & $22.25 \pm 0.95^{b}$ & $72.25 \pm 2.21^{\mathrm{b}}$ & $3.00 \pm 0.81^{\mathrm{b}}$ & $3.0 \pm 0.57^{\mathrm{b}}$ & $3.00 \pm 0.81^{\mathrm{b}}$ \\
\hline $\begin{array}{l}\mathrm{PHEE} \\
\mathrm{mg} / \mathrm{kg} \text { bw }\end{array}$ & $23.25 \pm 1.25^{\mathrm{b}}$ & $73.75 \pm 1.50^{\mathrm{b}}$ & $3.25 \pm 0.95^{\mathrm{b}}$ & $3.75 \pm 1.25^{\mathrm{b}}$ & $4.00 \pm 0.81^{\mathrm{b}}$ \\
\hline
\end{tabular}

Information:

PHNHE (poguntano herb n-hexane extract)

PHEAE (poguntano herb ethyl acetate extract)

PHEE (poguntano herb ethanol extract)

a. Sig $(\mathrm{P})<0.05$ there was a significant difference with the normal control group

b. Sig $(\mathrm{P})<0.05$ there was a significant difference with the negative group

c. Sig $(\mathrm{P})<0.05$ there was a significant difference with the levamisole group

a. lymphocytes

Table 2 shows that ENHHP was not significantly different from the negative group ( $\mathrm{p}>0.05$ ). EEAHP at doses of 50,100, $200 \mathrm{mg} / \mathrm{kg}$ bw and EEHP at doses of 50, 100, $200 \mathrm{mg} / \mathrm{kg}$ bw were significantly different from the negative group ( $\mathrm{p}<0.05)$. EEAHP at a dose of 100, $200 \mathrm{mg} / \mathrm{kg} \mathrm{BW}$ and EEHP at a dose of 50,100, $200 \mathrm{mg} / \mathrm{kg}$ bw were not significantly different from the levamisol and normal groups ( $p>0.05$ ). So that EEAHP at a dose of 100, $200 \mathrm{mg} / \mathrm{kg}$ bw and EEHP at a dose 
of $50,100,200 \mathrm{mg} / \mathrm{kg}$ bw were able to increase the number of lymphocytes in male white mice that were injected with cyclophosphamide.

\section{b. Neutrophils}

Table 2 shows that ENHHP was not significantly different from the negative group ( $>0.05)$. EEAHP at doses of 50,100, $200 \mathrm{mg} / \mathrm{kg} \mathrm{BW}$ and EEHP at doses of 50, 100, $200 \mathrm{mg} / \mathrm{kg}$ BW were significantly different from the negative group ( $\mathrm{p}<0.05$ ). EEAHP at a dose of 100, $200 \mathrm{mg} / \mathrm{kg} \mathrm{BW}$ and EEHP at a dose of 50,100, $200 \mathrm{mg} / \mathrm{kg}$ bw were not significantly different from the levamisol and normal groups ( $\mathrm{p}>0.05$ ). So that EEAHP at a dose of 100, $200 \mathrm{mg} / \mathrm{kg}$ bw and EEHP at a dose of $50,100,200 \mathrm{mg} / \mathrm{kg}$ bw were able to increase the number of neutrophils in male white rats injected with cyclophosphamide.

\section{c. Basophils}

Table 2 shows that ENHHP was not significantly different from the negative group ( $>0.05$ ). EEAHP at doses of 50,100, $200 \mathrm{mg} / \mathrm{kg}$ bw and EEHP at doses of 50, 100, $200 \mathrm{mg} / \mathrm{kg}$ bw were significantly different from the negative group $(\mathrm{p}<0.05)$. EEAHP at a dose of $100,200 \mathrm{mg} / \mathrm{kg} \mathrm{bw}$ and EEHP at a dose of 50,100, $200 \mathrm{mg} / \mathrm{kg}$ bw were not significantly different from the levamisol and normal groups ( $\mathrm{p}>0.05$ ). So that EEAHP at a dose of 100, $200 \mathrm{mg} / \mathrm{kg}$ bw and EEHP at a dose of $50,100,200 \mathrm{mg} / \mathrm{kg}$ bw were able to increase the number of basophils in male white rats that were injected with cyclophosphamide.

\section{d. Eosinophils}

Table 2 shows that ENHHP was not significantly different from the negative group ( $\mathrm{p}>0.05)$. EEAHP at doses of 50,100, $200 \mathrm{mg} / \mathrm{kg}$ bw and EEHP at doses of 50,100, $200 \mathrm{mg} / \mathrm{kg}$ bw were significantly different from the negative group $(\mathrm{p}<0.05)$. EEAHP at a dose of 100, $200 \mathrm{mg} / \mathrm{kg} \mathrm{BW}$ and EEHP at a dose of 50,100, $200 \mathrm{mg} / \mathrm{kg}$ bw were not significantly different from the levamisol and normal groups ( $\mathrm{p}>0.05$ ). So that EEAHP at a dose of 100, $200 \mathrm{mg} / \mathrm{kg}$ bw and EEHP at a dose of $50,100,200 \mathrm{mg} / \mathrm{kg}$ bw were able to increase the number of eosinophils in male white rats injected with cyclophosphamide.

\section{e. Monocytes}

Table 2 shows that ENHHP was not significantly different from the negative group ( $\mathrm{p}>0.05$ ). EEAHP at doses of 50,100, $200 \mathrm{mg} / \mathrm{kg}$ bw and EEHP at doses of 50,100, $200 \mathrm{mg} / \mathrm{kg}$ bw were significantly different from the negative group $(\mathrm{p}<0.05)$. EEAHP at a dose of $100,200 \mathrm{mg} / \mathrm{kg} \mathrm{bw}$ and EEHP at a dose of 50,100, $200 \mathrm{mg} / \mathrm{kg}$ bw were not significantly different from the levamisol and normal groups ( $p>0.05$ ). So that EEAHP at a dose of 100, $200 \mathrm{mg} / \mathrm{kg}$ bw and EEHP at a dose of $50,100,200 \mathrm{mg} / \mathrm{kg}$ bw were able to increase the number of monocytes in male white rats that were injected with cyclophosphamide.

This study showed that cyclophosphamide was able to significantly reduce the total number of leukocytes. The decrease in the total number of leukocytes in this study was one of the acute symptoms of cyclophosphamide administration. This is due to the suppressive effect of cyclophosphamide on the bone marrow which will inhibit the formation of blood cells including leukocytes.

The increase in lymphocytes, neutrophils, eosinophils, basophils and monocytes is caused by the presence of flavonoid compounds contained in ethyl acetate extract and ethanol extract of poguntano herb (PicriaFel-Terrae Lour.), Flavonoid compounds have the potential to act on 
lymphokines produced by $\mathrm{T}$ cells to stimulate cells- phagocytic cells to carry out the phagocytosis response [14].

\section{Conclusion}

This study shows that ENHHP can not increase the total and differential leukocytes; EEAHP, EEHP at doses of 100 and $200 \mathrm{mg} / \mathrm{kgbw}$ were effective in increasing the total and differential leukocytes. EEAHP, EEHP has effective immunostimulating activity.

\section{Acknowledgement}

This research was funding by Ministry of Research and Technology/National Agency for research and Innovation through "Hibah Penelitian Dasar Unggulan Perguruan Tinggi" research grant 20182020 .

\section{REFERENCES}

[1]. A.K. Abbas, A.H. Licthtman, dan Pillai, S. Imunologi Dasar Fungsi dan Kelainan Sistem Imun. Edisi Indonesia kelima. Penerjemah: Handono Kalim. Elsevier, p. 1-25, 35, 47, 55.2016

[2]. B.S. Kresno, Imunologi: Diagnosis dan Proses Laboratorium. Edisi 4. Jakarta: Balai Penerbit Fakultas Kedokteran Universitas Indonesia.p 5, 10-12.2001

[3]. H. L. Weiner and J. A. Cohen, "Treatment of multiple sclerosis with cyclophosphamide: critical review of clinical and immunologic effects," Multiple Sclerosis Journal, vol. 8, no. 2, pp. 142-154, Apr. 2002.

[4]. Buisman, T. L. Van Zwet, Langermans, M. F. Geertsma, Leenen, and Van Furth, "Different effect of granulocyte colony-stimulating factor or bacterial infection on bone-marrow cells of cyclophosphamide-treated or irradiated mice,” Immunology, vol. 97, no. 4, pp. 601-610, Aug. 1999.

[5]. A. Hussain, W. Shadma, A. Maksood, and S. Ansari, "Protective effects of Picrorhiza kurroa on cyclophosphamide-induced immunosuppression in mice," Pharmacognosy Research, vol. 5, no. 1, p. 30, 2013.

[6]. M. Pittler, "Immunomodulatory Agents from Plants," Focus on Alternative and Complementary Therapies, vol. 5, no. 3, pp. 233-233, Jun. 2010.

[7]. A. Dalimunthe, ,P.A. Z Hasibuan, P.A.Z. danErnawaty. "Aktivitas Imunomodulator Ekstrak Etanol PogunTanoh (Curangafel-terrae)", Pharmacy update 3. Seminar workshop. IAI. Medan.p 1-4. 2011

[8]. D. Satria, J. Silalahi, G. Haro, and S. Ilyas, "Antiproliferative and Apoptotic Induction of nHexane Fraction of Picria fel-terrae lour. Herbs on T47D Cell Line," Proceedings of BROMO Conference, 2018.

[9]. N. AuliaFendri, Rosidah, Yuandani, S. Suryani, and D. Satria, "The Immunomodulatory Activities of Picria Fel-Terrae Lour Herbs towards RAW 264.7 Cells," Open Access Macedonian Journal of Medical Sciences, vol. 7, no. 1, pp. 24-28, Jan. 2019.

[10].Z. Mufidah, M.Rifa'i, dan S.Rahayu, "Aktivitas Imunomodulator Ekstrak Buah Mengkudu pada Mencit yang Diinfeksi Staphylococcus aureus". Jurnal veteriner. vo14. No.4, p. 501$510,2013$.

[11].A. Emadi, R. J. Jones, and R. A. Brodsky, "Cyclophosphamide and cancer: golden anniversary," Nature Reviews Clinical Oncology, vol. 6, no. 11, pp. 638-647, Sep. 2009.

[12].V. Aeri, U. Ilyas, D. Katare, and P. Naseef, "A review on hepatoprotective and immunomodulatory herbal plants," Pharmacognosy Reviews, vol. 10, no. 19, p. 66, 2016.

[13].H. Zola, "Medical Applications of Leukocyte Surface Molecules - the CD molecules," Molecular Medicine, vol. 12, no. 11-12, pp. 312-316, Nov. 2006. 
[14].S.K. Kusmardi, dan E.T. Enif, "Efek Imunomodulator Ekstrak Daun Ketepeng Cina (Cassia alata. L) terhadap Aktivitas dan Kapasitas Fagositosis Makrofag. Makara Kesehatan. 11(2): 50-51. Halaman 1-7 2007 